\title{
Discourse on the formulation of the Jarimah of sexual violence against children in the
} Aceh Qanun Jinayat

\author{
Discurso sobre a formulação do Jarimah da violência sexual contra crianças em Aceh Qanun
}

Jinayat

Discurso sobre la formulación de la Jarimah de la violencia sexual contra los niños en Aceh Qanun

Jinayat

Received: 08/31/2021 | Reviewed: 09/03/2021 | Accept: 09/07/2021 | Published: 09/09/2021

\author{
Liza Agnesta Krisna \\ ORCID: https://orcid.org/0000-0002-5994-8205 \\ Faculty of Law, University of Samudra, Indonesia \\ Faculty of Law, University of Brawijaya, Indonesia \\ E-mail: agnes_krisna@unsam.ac.id \\ I Nyoman Nurjaya \\ ORCID: https://orcid.org/0000-0002-2000-3036 \\ Faculty of Law, University of Brawijaya, Indonesia \\ E-mail: inyoman@ub.ac.id \\ Prija Djatmika \\ ORCID: https://orcid.org/0000-0003-0262-8718 \\ Faculty of Law, University of Brawijaya, Indonesia \\ E-mail: prija.djatmika@ub.ac.id \\ Nurini Aprilianda \\ ORCID: https://orcid.org/0000-0003-3956-3081 \\ Faculty of Law, University of Brawijaya, Indonesia \\ E-mail: nurini.aprilianda@ub.ac.id
}

\begin{abstract}
The implementation of Islamic law in Aceh is based on the special autonomy and privileges of Aceh. The implementation of Islamic law brings the spirit of formalizing Islamic teachings through formal state regulations, namely the Aceh Qanun. Qanun Jinayat is a regulation that regulates disgraceful acts that should be punished in the teachings of Islamic law or can be referred to as a compilation of criminal law in Aceh. There are ten types of jarimah (criminal acts) regulated in the Qanun Jinayat, two of which are jarimah of sexual harassment and jarimah of rape. During the implementation of the Qanun Jinayat related to the law enforcement of the crime of sexual violence against children, both crimes of sexual harassment and rape have attracted a lot of criticism from the public, this crime is seen as no longer regulated in the Qanun Jinayat because it has been regulated previously and is more complete in the Child Protection Law. The ratio legis for regulating sexual violence against children in the Qanun Jinayat is because this act is seen as a continuation of the act of khalwat. This study shows an inaccuracy in the formulation of the type of jarimah in the Qanun Jinayat and the neglect of horizontal harmonization of national law.
\end{abstract}

Keywords: Sexual violence; Children; Qanun jinayat.

\section{Resumo}

A implementação da lei islâmica em Aceh é baseada na autonomia e privilégios especiais de Aceh. A implementação da lei islâmica traz o espírito de formalização dos ensinamentos islâmicos por meio de regulamentos estaduais formais, ou seja, o Aceh Qanun. Qanun Jinayat é um regulamento que regula atos vergonhosos que devem ser punidos nos ensinamentos da lei islâmica ou pode ser referido como uma compilação da lei criminal em Aceh. Existem 10 tipos de jarimah (atos criminosos) regulamentados no Qanun Jinayat, dois dos quais são jarimah de assédio sexual e jarimah de estupro. Durante a implementação do Qanun Jinayat relacionado à aplicação da lei do crime de violência sexual contra crianças, ambos os crimes de assédio sexual e estupro atraíram muitas críticas do público, este crime é visto como não mais regulamentado no Qanun Jinayat porque já foi regulamentado anteriormente e é mais completo na Lei de Proteção à Criança. A ratio legis para a regulamentação da violência sexual contra crianças no Qanun Jinayat é porque este ato é visto como uma continuação do ato de khalwat. Este estudo mostra que há uma imprecisão na formulação do tipo de jarimah no Qanun Jinayat e a negligência da harmonização horizontal da legislação nacional. Palavras-chave: Violência sexual; Crianças; Qanun jinayat. 


\section{Resumen}

La implementación de la ley islámica en Aceh se basa en la autonomía y privilegios especiales de Aceh. La implementación de la ley islámica trae el espíritu de formalizar las enseñanzas islámicas a través de regulaciones estatales formales, a saber, Aceh Qanun. Qanun Jinayat es un reglamento que regula los actos vergonzosos que deben ser castigados según las enseñanzas de la ley islámica o pueden denominarse una compilación de leyes penales en Aceh. Hay 10 tipos de jarimah (actos criminales) regulados en Qanun Jinayat, dos de los cuales son jarimah de acoso sexual y jarimah de violación. Durante la implementación del Qanun Jinayat relacionado con la aplicación de la ley del delito de violencia sexual contra niños, tanto los delitos de acoso sexual como la violación han atraído muchas críticas del público, este delito ya no se considera regulado en el Qanun Jinayat. porque ha sido regulado anteriormente y es más completo en la Ley de Protección a la Niñez. La ratio legis para la regulación de la violencia sexual contra los niños en Qanun Jinayat se debe a que este acto se considera una continuación del acto de khalwat. Este estudio muestra que existe una inexactitud en la formulación del tipo de jarimah en el Qanun Jinayat y el descuido de la armonización horizontal de la legislación nacional.

Palabras clave: Violencia sexual; Niños; Qanun jinayat.

\section{Introduction}

One of the crimes against children that continues to increase is sexual violence. Even this crime is called an iceberg phenomenon. This is because most children who become victims of sexual violence are afraid to report to their parents or family. Children do not understand the treatment they face, so that children only accept their helplessness. Sexual violence in various forms against children is worrying in contrast to sexual violence against adults, where the victims are more women. Meanwhile, victims of sexual violence experienced by children are not only girls but also boys.

The increase in cases of sexual violence against children can be seen from two sides. First, public awareness to report cases of sexual violence against children and women. People are starting to realize and think that sexual violence is a crime against humanity and a crime against children and women, so it doesn't need to be covered up, and it is not a disgrace. Second, there has been an increase in quantitative or real because the parties involved in this crime have turned to children, related to the increasing number of cases of the person living with HIV/AIDS. Children are considered more sterile, do not carry venereal diseases than adults (Ghufran, 2015).

Several regulations governing the protection of children show the government's attitude that cares about the sustainability of the nation's generation and the government's response to the condition of children who are vulnerable to being victims of criminal acts. A child who is a victim of a criminal act after this, referred to as a child of the victim, is a child who is not yet 18 years old who causes the child to experience physical suffering, mental suffering, and/or economic loss caused by a criminal act (Aprilianda, 2017).

The enactment of Law Number 23 of 2002, which was amended by Law Number 35 of 2014 concerning Amendments to Law Number 23 of 2002 concerning Child Protection and then underwent the second amendment in Law Number 17 of 2016 concerning the Second Amendment of Law Number 23 of 2002 concerning Child Protection (hereinafter referred to as the Child Protection Act) is a series of efforts made by the State to realize the fulfillment of child welfare because the main orientation of legal protection provided by the State and the government, of course, leads to the welfare of children.

Crimes of sexual violence against children in Aceh have also increased. Forms of sexual violence such as sexual harassment, rape, and sodomy against children since 2016-2017 reached 240 cases. The number of cases in Aceh, the most occurred in North Aceh 123 cases, followed by Banda Aceh City 94 cases, Aceh Besar 81 cases, Bireuen 69 cases, Pidie 57 cases, Bener Meriah 52 cases, Aceh Tengah 45 cases, and Aceh Timur 35 cases. Meanwhile, for other regencies/cities, the violence rate was below 30 cases on average.

Law enforcement in cases of sexual violence against children in Aceh has different regulations used with other provinces. This difference is due to an organic regulation in Aceh called Qanun (Zeidan, 2000). Qanun Number 6 of 2014 
concerning Jinayat Law (hereinafter referred to as Qanun Jinayat) was ratified on 22 October 2014 (Lubis \& Ritonga, 2016). The Qanun of Jinayat Law includes 10 (ten) chapters and 75 (seventy-five) articles. There are 10 (ten) criminal acts called Jarimah (Marsum, 1988) regulated in the Jinayat Qanun, including:
a) Jarimah Khamar;
b) Jarimah Maisir;
c) Jarimah Khalwat;
d) Jarimah Ikhtilat;
e) Jarimah Zina;
f) Jarimah of Sexual Harassment;
g) Jarimah Rape;
h) Jarimah Qadzaf;
i) Jarimah Liwath, and;
j) Jarimah Musahaqah.

The enactment of the Qanun Jinayat affects the protection of children in Aceh both in material and formal terms. Jinayat Qanun materially regulates the criminal act of sexual harassment of children in Article 47 and the criminal act of raping children, which is in Article 50 of the Jinayat Qanun. Both of the criminal acts have been explicitly regulated in the national law, namely Child Protection Act. Meanwhile, from a formal point of view, the issue of authority for the judicial process of the Jinayat Law Qanun is carried out at the Syar'iyah Court (Lubis \& Ritong, 2016).

Criticism of the application of the Qanun Jinayat in cases of violence against children has reached the national level. Some fundamental differences in terms of sanctions in setting norms for criminal acts of sexual violence against children between the Child Protection Act and the Qanun Jinayat caused reactions in the society. The Ministry of Women's Empowerment and Child Protection responded to the acquittal of the child rape case by a man against his nephew, which the Aceh Sharia Court determined on Thursday, 20 May 2021, "We want to explore further regarding the acquittal of perpetrators of sexual violence against children, because the verdict initially, he was accused to 200 months in prison. Therefore, the Ministry of Women's Empowerment and Child Protection scientifically wants to examine the position of Qanun in national legislation from various perspectives. Is there an overlapping regulation, and how is it compatible with the Child Protection Act and related to women's protection so that synchronization can be realized," said the Special Staff of the Ministry of Women's Empowerment and Child Protection, Ulfah Mawardi, in the online event to review the position of Qanun in National Legislation.

Based on the description above, this study aims to reveal the ratio legis of the regulation of sexual violence against children in the Qanun Jinayat and find the juridical implications resulting from the regulation of criminal acts of sexual violence against children in the Qanun Jinayat. Thus, this research will lead to systemic steps that the Aceh Government must take as a commitment to implement child protection from criminal acts of sexual violence.

\section{Methodology}

Research is the main means in the development of science and technology (Soekanto \& Mamudji, 2013). The method used in this research is normative legal research, namely research that is focused on examining the application of the rules in positive law (Poesoko, 2013), there is no need to support data or social facts (Nasution, 2008). The materials used in this 
research are primary legal materials in the form of statutory regulations and secondary legal materials in legal literature relevant to the issues discussed (Marzuki, 2011). In legal research, several approaches aim to obtain information from various aspects of the matter sought answers (Ibrahim, 2008). In this connection, in writing this article using a statutory approach and a conceptual approach.

\section{Results and Discussion}

\subsection{The Ratio legis of Sexual Violence Against Children in the Qanun Jinayat}

The ratio legis can be interpreted as the reason for being made the legal provision. Ratio Legis is also a subjective goal of the law, the intention which the lawgiver or judge builds. A type of legal argument constructed by the intention or reason of the lawgiver (or judge). This becomes all the objective goals of the relevant legislation in certain circumstances. A justification (external, justification) for a particular legislative or judicial act (Klappstein \& Dybowski, 2018). Therefore, the ratio legis of a law provision cannot be separated from the ontological basis or the philosophical basis of the law that contains the provision.

To determine the ratio legis of the regulation of sexual violence against children in the Qanun Jinayat, namely sexual harassment and rape, it is necessary to examine the philosophical (ontological) basis for the formation of Qanun Number 6 2014 concerning Jinayat Law. Articles relating to sexual violence against children in the Jinayat Law are contained in Article 47 concerning the offense of sexual harassment and Article 50 concerning the crime of rape, with the following details:

Article 47 regulates criminal sanctions against perpetrators of sexual harassment/obscenity towards children, which reads:

Everyone who intentionally commits sexual harassment, as referred to in Article 46 against children threatened with 'Uqubat Ta'zir whips at most 90 (ninety) times or a maximum fine of 900 (nine hundred) grams of pure gold or imprisonment for a maximum of 90 (ninety) months.

Furthermore, criminal sanctions for perpetrators of raping children are contained in Article 50, which reads:

Everyone who intentionally commits rape as referred to in Article 48 against a child, threatened with 'Uqubat Ta'zir whips at least 150 (one hundred and fifty) times, at most 200 (two hundred) times or a fine of a minimum of 1.500 (one thousand five hundred) grams of pure gold, a maximum of 2.000 (two thousand) grams of pure gold or imprisonment for a minimum of 150 (one hundred and fifty) months, a maximum of 200 (two hundred) months.

For the results of this study to be coherent, before finding the ratio legis of the regulation of sexual violence against children in the Qanun Jinayat, firstly, it is essential to understand the philosophical (ontological) basis of the Qanun Jinayat. To find out the philosophical (ontological) basis for the formation of the law, it can be observed in the considerations, legal basis and general explanation (Marzuki, 2005). The considerations is the opening part that begins with the word "considering," while the legal basis is the opening part that begins with "In view of." The considerations contain a brief description of the main ideas and the reasons for the formation of the law. The main ideas in the considerations contain the philosophical, sociological, and juridical elements that are considered and the reasons for their formation which are described sequentially.

Regarding the philosophical (ontological) basis of Qanun Jinayat, it can be observed in the considerations and general explanations, namely:

a. that the Al-Qur'an and Al-Hadith are the main foundations of the religion of Islam which bring mercy to all nature and have become the beliefs and life guidelines of the Acehnese people;

b. that in the framework of implementing the Memorandum of Understanding between The Government of the 
Republic of Indonesia and the Free Aceh Movement, in Helsinki at 15 August 2005, the Government of the Republic of Indonesia and the Free Aceh Movement affirm their commitment to resolving the conflict Aceh in a peaceful, comprehensive, sustainable and dignified manner for all, and the parties are determined to create conditions so that the Acehnese People's Government can be realized through a democratic and fair process within the Unitary State of the Republic of Indonesia;

c. that Aceh as part of the Unitary State of the Republic of Indonesia has special privileges and autonomy, one of which is the authority to implement Islamic Sharia, by upholding justice, benefit, and legal certainty;

d. that based on the mandate of Article 125 of Law Number 11 of 2006 concerning the Government of Aceh, the Jinayat Law (criminal law) is part of the Islamic Shari'ah implemented in Aceh.

The considerations description provides a brief explanation of the philosophical (ontological) basis of the Qanun Jinayat. In this consideration, Islam is the belief and guide for the life of the Acehnese people. The Acehnese people are known as a community that is obedient and fanatical to Islamic law. This is evidenced by the history of the civilization of the Acehnese people during the sultanate before being united within the framework of the Republic of Indonesia. The Acehnese people (Dhuhri, 2017) have made religious norms standard to measure an act according to or not with the Shari'ah. Every Muslim believes that Islamic law is a way of life that can bring happiness and safety in this world and the hereafter.

Furthermore, the Acehnese people have championed this belief since the old order, the new order until now. Human rights violations in Aceh took place so violently, destroying the dignity of the Acehnese people. Until finally, a peace agreement was reached through a Memorandum of Understanding between the Government of the Republic of Indonesia and the Free Aceh Movement. Based on the Memorandum of Understanding, the Acehnese people received special privileges and autonomy to implement Islamic law, including the legitimacy of the formation of the Qanun Jinayat.

In addition to the "weighing" consideration, this research is continued on the "remembering" or legal basis stated in the Qanun Jinayat, which is as follows:

a. Article 18 paragraph (6), Article 18B, and Article 29 of the 1945 Constitution of the Republic of Indonesia;

b. Law Number 24 of 1956 concerning the Establishment of the Autonomous Region of the Aceh Province and the Amendment to the Regulations for the Establishment of the Province of North Sumatra (State Gazette of the Republic of Indonesia of 1956 Number 64, Supplement to the State Gazette of the Republic of Indonesia Number 1103);

c. Law Number 44 of 1999 concerning the Implementation of the Privileges of the Province of the Special Region of Aceh (State Gazette of the Republic of Indonesia of 1999 Number 172, Supplement to the State Gazette of the Republic of Indonesia Number 3892);

d. Law Number 11 of 2006 concerning the Government of Aceh (State Gazette of the Republic of Indonesia of 2006 Number 62, Supplement to the State Gazette of the Republic of Indonesia Number 4633).

The description of the considerations determines the legal basis for the application of the Qanun Jinayat to the Constitution of the Republic of Indonesia, which is used as the legal basis for each of which reads:

a) Article 18 paragraph (6)

"Local governments have the right to stipulate regional regulations and other regulations to carry out autonomy and assistance tasks." 


\section{b) Article $18 \mathrm{~B}$}

"The state recognizes and respects customary law community units and their traditional rights as long as they are still alive and in accordance with community development and the principles of the Unitary State of the Republic of Indonesia, which are regulated by law."

c) Article 29

"The state is based on the one and only God, and the state guarantees the independence of each resident to embrace their religion and to worship according to their religion and beliefs."

While number 2, number 3, and number 4 are in the "remembering" considerations, the legal basis states the existence of special rights and special autonomy for Aceh, which are recognized and guaranteed by the central government. Based on these "remembering" considerations, implementing Islamic law through the implementation of the Islamic Jinayat Qanun in Aceh has strong legality.

After researching the "weighing" and "remembering" considerations, it is continued by observing and understanding the general explanation section of the Qanun Jinayat. In the general explanation, which found the following explanation:

At present, the implementation of Islamic law in Aceh is a mandate and command of at least 3 (three) laws, namely:

1. Law Number 44 of 1999 concerning the Implementation of the Privileges of the Province of the Special Region of Aceh;

2. Law Number 11 of 2006 concerning the Government of Aceh, and;

3. Law Number 48 of 2007 concerning Stipulation of Government Regulation in Lieu of Law Number 2 of 2007 concerning Handling of Legal Issues in the Framework of Implementing Rehabilitation and Reconstruction of Territories and Community Life in the Province of Nanggroe Aceh Darussalam and Nias Islands, Province of North Sumatra.

There is one other law regarding special autonomy in Aceh, namely Law Number 18 of 2001, concerning Special Autonomy for the Province of the Special Region of Aceh as the Province of Nanggroe Aceh Darussalam. This law introduces the Qanun as a forum for Islamic law to be implemented as positive law in Aceh as part of the national legal system. Based on the law for the first step, 3 (three) qanuns were passed:

a. Qanun of the Province of Nanggroe Aceh Darussalam Number 12 of 2003 concerning Alcoholic Drinks and the Like;

b. Qanun of Nanggroe Aceh Darussalam Province Number 13 of 2003 concerning Maisir (Gambling) and;

c. Qanun of the Province of Nanggroe Aceh Darussalam Number 14 of 2003 concerning Seclusion.

The selection of the three issues above to be written into the Qanun as the initial Qanun in the criminal field was carried out for at least two considerations: first, these acts are immoral in the Shari'ah and are relatively very disturbing to the Acehnese people, but have not been handled properly. The act of drinking alcohol and committing seclusion are not criminal acts in the national criminal law, while maisir only those who do not get a permit are criminal acts in the national criminal law. Second, there was euphoria in various levels of Acehnese people, in the form of "people's courts" that appeared in the community for the three types of criminal acts above, immediately after Law Number 44 of 1999 was passed.

The main principles that serve as guidelines, as well as the method of writing draft qanuns on the implementation of Islamic law from the perspective of ushul fiqh, there are four main points (principles) that become the main guidelines that 
need to be stated in this explanation:

a. The provisions to be implemented must still be sourced from the Qur'an and the Sunnah of the Prophet.

b. The interpretation or understanding of the Al-Qur'an and Hadith will be related to the local conditions and needs of the Acehnese people in particular or the Indonesian Malay world in general, as well as the rules and regulations that apply within the framework of the Unitary State of the Republic of Indonesia.

c. This interpretation and understanding will be strived to always be future-oriented to meet the needs of the Indonesian people who are developing in the early fifteenth century or twenty-one century and can respond to the "spirit" of modern era as reflected in the issue of human rights protection and gender equality, as well as consider the development of science and technology, especially the science of law, whose development is relatively very fast and rapid.

d.To complete the three principles above, it is guided by the principles contained in a widely known fiqh kulliah rule, al-muhafazhah 'ala-I qadim-ish shalih wa-I akhdzu bi-I Jadid-il ashlah which means more or less "still interpreting the old provisions that are still good (relevant) and trying to find and formulate new provisions that are better and superior. Jarimah in this Qanun is trying to protect morals."

Based on the results of the research on the "weighing" and "remembering" considerations that were traced and also the body as well as the general explanation of the Qanun Jinayat, the philosophical basis for the formulation of the Qanun Jinayat can be stated as follows:

1. Islam is the belief and way of life of the Acehnese people. The Acehnese people have made religious norms standard for measuring an act in accordance with the Shari'ah or not. Every Muslim believes that Islamic law is a way of life that can bring happiness and safety in this world and the hereafter.

2. Based on The Memorandum of Understanding between the Government of the Republic of Indonesia and the Free Aceh Movement (Memorandum of Understanding between The Government of the Republic of Indonesia and the Free Aceh Movement, Helsinki 15 August 2005), Acehnese people get special privileges and autonomy to implement Islamic law, including the legitimacy of the formation of Qanun Jinayat Law.

3. The establishment and enforcement of the Qanun Jinayat in Aceh as part of the national legal system is constitutional.

4. The provisions to be implemented must still be sourced from the Qur'an and the Sunnah of the Prophet, including the regulation of the types of jarimah in the Qanun Jinayat, where these acts are declared as immoral acts in Islamic law and are not criminal acts in national criminal law.

In addition to research the ratio legis through the above pattern, this research can also be carried out through original intent searches. Original intent is one pattern of interpretation of a constitution or law. Original intent is a method of interpretation using the intent or intention of forming the legal norm itself and formulating it into the legal norm. Therefore, the perspective used in the original intent method is historical, so that it can be called one variant of the historical interpretation approach (Ashidiqqie, without year).

After issuing Law Number 18 of 2001, the Aceh Government formed the committee to collect materials, determine areas and steps of work and write a draft Aceh qanun regarding the implementation of Islamic law as Aceh's positive law. The Jinayat sector (material and formal) is a priority for the Qanun to be written (Abubakar \& Lubis, 2019). 
Qanun and governor regulations relating to protecting morals, decency, and self-respect (moral and moral nobility). This issue is a top priority for consideration. First, the problem of morals, especially immorality, seclusion, and alcohol which is forbidden in Islamic law, has deeply disturbed the people of Aceh but has not been handled properly. Second, "the act of drinking khamr and doing seclusion is not a criminal act in national law, while maisir only those who do not get permission are criminal acts." Third, "there was euphoria in various levels of society in Aceh, in the form of "people's courts" that appeared in the community for the three types of criminal acts above, immediately after Law Number 44 of 1999 was passed. Between September and December 1999, there were dozens of cases in the three problems above, which were resolved by the community through "people's courts" in various places in Aceh" (Bakar, 2008).

After the Aceh Government issued 3 (three) criminal qanuns in 2003, namely the Qanun of the Province of Nanggroe Aceh Darussalam concerning Khamar, Maisir, and Khalwat. In trials of implementing qanuns in the field, what police, prosecutors, and judges feel when using and implementing these qanuns, as well as questions, criticisms, and suggestions submitted by academics, practitioners, implementers, and observers in the field both during the process investigation by the police, prosecution by the Prosecutor's Office and trial by the Syar'iyah Court, or during socialization, coordination and evaluation activities or other discussions (whether formal or informal), there are several questions and criticisms of various provisions in the qanuns above which cannot be answered properly. There is a vagueness in the definition, ambiguity, and incompleteness of regulatory norms that create difficulties in practice. It needs to be refined and added in the field of material law. The proposals revolve around:

1. Some of its meanings, such as definitions, gambling, and seclusion, are considered not firm and even too flexible to have the potential for multiple interpretations. The definition of children and the protection of children are not yet fully and adequately regulated.

2. Attempts to commit criminal acts and participation are also not regulated clearly

3. The ratio and comparison between caning, fines, and imprisonment is not clear, so it seems inconsistent

4. The minimum and maximum punishment limits set out in the Qanun are felt to be too rigid. There is an assumption that the minimum penalty (at least in some cases) is too high, and conversely, the maximum penalty (at least in some cases) is considered too low.

5. The problem of non-Muslims or soldiers who violate the Qanun or commit criminal acts together with Muslims (Bakar, 2008).

This situation then strengthened the plan for the improvement and development of the Qanun in the field of jinayat in Aceh. This draft of Qanun was given the name "Aceh Qanun on the 2008 Jinayat Law Compilation" (Bakar, 2008). In this draft, like the three previous jinayat qanuns, there is still a combination of material and formal law. In the same year (2007), the draft was submitted to the Legal Bureau of the Aceh Government. In the development, in 2008 (discussed in 2009), after the draft was submitted to the DPRA, there was an agreement with DPRA so that the draft qanun on jinayat law be separated into two parts, namely: the draft qanun on jinayat law and the draft qanun on jinayat procedure law. Likewise, the criminal act is added to 3 (three) jarimah, namely liwath, musahaqah, and qadzaf, so that the number of types of jarimah in the raqan of jinayat law becomes 9 (nine). In the legislative process, 1 (one) more is added, namely the crime of sexual harassment. These ten jarimah (crime) were then discussed until later ratified into Qanun Number 6 of 2014 concerning Jinayat Law on 22 October 2014.

Furthermore, after finding and understanding the philosophical basis for the formation of the Qanun Jinayat, the 
research is continued to find the ratio legis the regulation about the crime of sexual violence against children. The basis of consideration of the formulation of the crime of sexual harassment and rape of children, as stated in Article 47 and Article 50 of the Qanun Jinayat, can be found in the Academic Paper of the 2008 Draft Qanun. In the Academic Paper, it is written that:

Completion of a rather broad definition is carried out on the notion of seclusion. In Qanun 14/03, seclusion has two definitions. One definition is included in article 1, and another definition is included in the official explanation. The definition of khalwat in Article 1 Number 20 is maintained, not changed, namely khalwat/mesum is an act of silence between two mukallaf of different sexes who are not married or without marriage ties. While the definition of khalwat stated in the general explanation is used as a new jarimah which is named ikhtilath, namely the act of making out (having fun) between men and women who are not husband and wife.

Furthermore, other acts that are closely related to seclusion are added, namely adultery and rape. The act's definition is as follows: adultery is the intercourse of a man with a woman who is not his wife, with the willingness of both parties. Rape is the act of a man intentionally forcing a woman who is not his wife to have intercourse with him. These three actions are included as jarimah in the design of changes and improvements to this Qanun because they are closely related to and even a continuation of the act of seclusion. This means that people who do seclusion will usually continue with the act of ikhtilath. Even some will continue to adultery or rape.

From the excerpt of the academic text above, it is revealed that the consideration of the inclusion of the criminal acts (jarimah) of ikhtilat, adultery, and rape is because the three kinds of jarimah are acts that are closely related to and even a continuation of the act of seclusion. However, there is no mention of sexual harassment in the academic text. However, it can be understood that this jarimah is the same type as the three types of jarimah, which is an act that violates decency.

The author tries to understand the intent of the formulator of the Qanun on the meaning of "continued action from seclusion" by explaining that, first: there is a God's Word in QS al-Israa': 32, "and do not approach adultery; verily, adultery is an abominable act and a bad way." This is the basis of the prohibition of the jarimah of seclusion to prevent oneself from committing adultery. The prohibition of adultery begins with actions that lead to adultery. Logically, it can be understood that if approaching, it is forbidden, let alone committing adultery itself. This meaning is obtained because the act of adultery is understood as more understanding than (just) the act of introducing adultery. The sentence in QS al-Israa': 32 above is a statement of prohibition. There are no sanctions in verse.

Second, the sanctions for adultery based on the Word of Allah are contained in QS an-Nuur: 2, "the act of adultery and the man who commits adultery, then lash each one of them a hundred lashes, and do not be merciful to both of them prevent you to practice the religion of Allah, if you believe in Allah and the hereafter, then let a group of believers witness their punishment." The verse explains the sanctions for adultery concretely. So this is understood as part of 'uqubat hudud.

Third, then what is meant by adultery? In the Asy-Shafi'iyah School, the definition of the term adultery is inserting the testicles into the farji that is forbidden, lidzatihi, which is syahwati, in a state that is not mistaken (Al-Jurjani, without year). Sex here is defined as sex between the genitals of men and women who meet each other even though they do not release sperm.

Fourth, while in the Qur'an and hadith, it is not stated whether the act of adultery was done consensual or there was coercion or threats of violence. It is not even explained in the text that it is carried out on adult women or children. Matters relating to these conditions can be found in jurisprudence law. So if it is drawn from the basic law, then the act of inserting the penis into the farji that is forbidden, lidzatihi, which is syahwati, in a state not doubtful, (which is prohibited from being interpreted without a marriage bond) is an act of adultery, regardless of whether the act was consensual or forced or there were threats of violence against both women and children. This continued action of seclusion means that the basic law/origin of the three jarimah is seclusion.

Fifth, but in its development, the crime of adultery is given qualifications, namely the crime of adultery or the crime 
of rape or sexual harassment, the crime of adultery committed against a child or adult woman, the crime of rape against a child or adult woman, and the crime of sexual harassment against a child or adult woman.

Lastly, about the sanctions against adultery, sexual harassment, and rape, uqubat hudud is applied against adultery (the punishment is clear in the text). In contrast, sexual harassment is categorized as 'uqubat takzir. Islamic law punishes adultery with very severe punishment for adultery because these acts destroy human honor in general. Sexual harassment is included in the category of damaging human honor. Therefore the perpetrators of sexual harassment, especially when it comes to acts of sexual violence, must also be given severe punishment according to the level of harassment committed (Nur, 2016). Likewise with rape, in the view of Islam, forced adultery is an act of rape and is a sexual crime that must be severely punished (Saleh, 2008). Rape is a form of violence and oppression against women. All forms of oppression are violations of human rights. The sanctions in the Qanun Jinayat Law are formulated in 'uqubat takzir and exceed the sanctions for adultery.

Based on the description of the overall research on the ratio legis to the formation of the Qanun Jinayat Law and the regulation of the types of sexual violence against children, namely Article 47 concerning Sexual Harassment and Article 50 concerning rape, in particular. So, the authors find the intentions or reasons for the considerations of the lawmakers in setting the norms mentioned above, are as follows:

1. Islam is the belief and way of life of the people of Aceh. The people of Aceh have made religious norms a standard for measuring an act in accordance with the Shari'ah or not;

2. The establishment of the Qanun Jinayat is part of implementing Islamic law in a kaffah manner. It is a mandate from the Memorandum of Understanding between the Government of the Republic of Indonesia and the Free Aceh Movement.

3. In the field of jinayat, become the priority of the Qanun that will be written is related to the protection of morals, decency, and self-respect (nobility of character and morals), so that indirectly the unity of the types of jarimah regulated in the Qanun Jinayat can be seen as a decency offense.

4. To fill the legal vacuum in the implementation of Islamic law in Aceh, where immoral/deplorable acts in Islamic law are not regulated in the national criminal law;

5. There was euphoria in various levels of society in Aceh, in the form of "people's courts" that appeared in the community for the three types of criminal acts of khamr, maisir and khalwat immediately after Law Number 44 of 1999 was passed;

6. Lawmakers understand the regulation of sexual harassment and rape crimes as a continuation of the act of seclusion. The act of seclusion can cause the perpetrator to be trapped in the act of adultery. At the same time, the act of adultery is defined as the meeting or insertion of male sex into female sex outside of marriage. The continuation of this act to acts of sexual harassment and rape is due to the elements of the same act, namely, meeting or inserting the sex of one party into the sex of another party outside of marriage and is still like an act of decency.

7. One of the improvements that are summarized in the Academic Paper of Qanun Jinayat Law is related to the issue of children and child protection which are deemed incomplete and inadequate.

Based on the results of the research found above, the authors see the seriousness of the Aceh Government in compiling provisions in the field of criminal law. There are improvements and developments from the previous year in 2003. There were 3 (three) qanuns, namely the Qanun of the Province of Nanggroe Aceh Darussalam Number 12 of 2003 concerning Alcoholic Drinks and the like; Qanun of Nanggroe Aceh Darussalam Province Number 13 of 2003 concerning Maisir 
(Gambling) and; Qanun of the Province of Nanggroe Aceh Darussalam Number 14 of 2003 concerning Seclusion, then refined in the Qanun Jinayat Law which consists of 10 (ten) types of jarimah.

This is in line with the theory of criminal law policy that the politics of criminal law is "a rational effort from the community in dealing with crime." In other words, carrying out criminal law politics means holding elections to achieve the best results of criminal legislation in the sense of fulfilling the requirements of justice and efficiency (Arief, 2017). Criminal law policy is a reasonable effort from the community in dealing with crime. These efforts must always experience a shift for the better towards progress. That's when the law is a human ethical conversation to produce justice, which is the basis of the interests of civilization.

However, the author argues that the choice of the type of jarimah for sexual abuse and rape of children is not the right thing. Even contradictory decisions on the grounds of consideration of the formation of the qanun jinayat by the lawmakers themselves.

Ontologically, the provisions in the Qanun Jinayat that will be implemented must still be sourced from the Qur'an and the Sunnah of the Prophet, where these actions are declared as immoral acts in Islamic law and are not criminal acts in national criminal law. In this case, the Qanun Jinayat has the authority to determine actions that previously were not crimes in the criminal law system in Indonesia become acts in the category of crimes (criminalization).

Therefore, the inaccuracy of setting the jarimah on sexual harassment and rape is based on the fact that the lawmakers are inconsistent with the philosophical (ontological) elements of the Qanun Jinayat. Both of these jarimah have been regulated in the national criminal law and have been declared a form of crime, namely in the Child Protection Act so that the legislators of the Qanun Jinayat repeat the form of criminalization.

Therefore, the government and Acehnese people must realize that consequences which the State gives to Aceh government related to the right to implement Shari'a, namely the obligation to show Islam as rahmatan lil alamin and prove The implementation of Islamic Shari'a is carried out in harmony and line with the principles and system of the Unitary State of the Republic of Indonesia. In other words, despite implementing Islamic Shari'a, the Acehnese government could locate and present itself as an inseparable part of the Unitary State of the Republic of Indonesia.

\section{Conclusion}

In formal juridical terms, the implementation of Islamic law in Aceh is based on Law Number 44 of 1999 concerning the Implementation of the Privileges of the Province of the Special Region of Aceh and Law Number 11 of 2006 concerning the Government of Aceh. These two laws observe the implementation of Islamic law as a whole, including the enforcement of jarimah (criminal acts) in the legal dimension of jinayat. The formulation of the Qanun Jinayat material is the result of ijtihad based on the Qur'an and Hadith, which is connected to the needs of the Acehnese people. Qanun Jinayat was drafted and enforced because some immoral acts in Aceh were often resolved in the form of a "people's court." After all, Shari'ah law was not accommodated in national law. The Aceh government responds to this situation as an urgency to form the Qanun Jinayat to provide justice and prosperity in the community.

However, in using the authority to form qanuns in Aceh, the Aceh Government and the makers of the Qanun Jinayat must be rational in choosing the accuracy in formulating the types of crime/jarimah in the Qanun Jinayat Law, as a reference for the direction of the development of criminal law in Aceh which is integrally correlated in the direction of development of national criminal law. How should the political selection of criminal law in Qanun Jinayat be in the dimensions of the substance of the implementation of Islamic law and consideration of the position of Qanun Jinayat in the dimension of national 
criminal law. Thus, it can create good criminal law that aims to protect and welfare the people and support consistency in the implementation of Islamic Shari'a in Aceh within the scope of criminal law politics.

\section{Reference}

Abubakar, A \& Lubis, Z. (2019). Hukum Jinayat Aceh (Sebuah Pengantar). Jakarta: Prenamedia Group.

Al-Jurjani. (without year). Al-Ta'rifat. Jeddah: al-Haromain.

Aprilianda, N. (2017). Perlindungan Anak Korban Kekerasan Seksual Melalui Pendekatan Keadilan Restoratif. Jurnal Arena Hukum, 10 (2), $2017,309-332$.

Ashidiqqie, J. (without year). Sumber Hukum dan Metode Penafsiran Konstitusi. Makalah

Bakar, A. (2008). Naskah Akademik Rancangan Qanun Hukum Jinayat. Banda Aceh: Dinas Syariat Islam Provinsi Nanggroe Aceh Darussalam

Bakar, A. (2008). Penerapan Syariat Islam: Upaya Penyusunan Fikih dalam Negara Bangsa. Banda Aceh: Dinas Syariat Islam Provinsi Nanggroe Aceh Darussalam.

Dhuhri, S. (2017). Aceh Serambi Mekkah (Studi tentang Peran Ibadah Haji dalam Pengembangan Peradaban Aceh). Jurnal Ilmiah Islam Futura, 16 (2), 188195.

Ibrahim, J. (2008). Teori dan Metodologi Penelitian Hukum Normatif. Malang: Bayumedia Publishing.

Klappstein, V \& Dybowski, M. (2018). Ratio Legis Philosophical and Theoretical Perspectives. Germany: Faculty of Law University of Passau Passau.

Kordi, M. (2015). Durhaka Kepada Anak (Refleksi Mengenai Hak \& Perlindungan Anak). Yogyakarta: Pustaka Baru Press.

Lubis, Z \& Ritonga, H. (2016). Dasar-Dasar Hukum Acara Jinayah. Jakarta: Prenamedia Group.

Marsum. (1988). Jinayat (Hukum Pidana Islam). Yogyakarta: Perpustakaan FH UII.

Marzuki, P. (2005). Penelitian Hukum. Jakarta: Prenada Media, hal 96-97.

Nasution, B.J. (2008). Metode Penelitian Ilmu Hukum. Bandung: Mandar Maju.

Nur, M. (2016). Mengenai Hukum Pidana Ideal Kemaslahatan Pidana Islam dan Pembaharuan Hukum Pidana Nasional. Yogyakarta: Deepublish.

Poesoko, H. (2013). Modul Mata Kuliah Metode Penelitian Hukum. Jember: Fakultas Hukum Universitas Jember.

Saleh. (2008). Kajian Fiqh Nawawi dan Fiqh Kontemporer. Jakarta: Rajagrafindo Persada.

Soekanto, S. \& Mamudji, S. (2013). Penelitian Hukum Normatif: Suatu Tinjauan Singkat. Jakarta: RajaGrafindo Persada.

Zeidan, A. (2000). Nadzraa fi al Syari'ah al Islamiyyah. Lebanon: Muassasah Ar Resalah.

Arief, B.N. (2017). Bunga Rampai Kebijakan Hukum Pidana: Perkembangan Penyusunan Konsep KUHP Baru. Jakarta: Kencana. 